EDITORIAL

\title{
INVESTIGACIÓN DE VANGUARDIA: EL ROL DE LA INTERDISCIPLINA
}

En estos tiempos la ciencia vive momentos de gran desarrollo. La interacción de una diversidad de investigadores dentro de equipos multidisciplinarios, cobra cada día mayor vigor y sus resultados son más y más asombrosos. Por ejemplo, la estructura genética con su secuencia y propiedades físicas y químicas es altamente estudiada en equipos formados por matemáticos, biólogos, físicos, químicos y especialistas de la información e informática. El área conocida como física mesoscópica es otro ejemplo de dicha interacción entre diferentes especialistas. En efecto, las propiedades electrónicas de sistemas de unos pocos micrómetros a bajas temperaturas, requieren la participación de ingenieros, físicos y matemáticos. Del mismo modo, problemas tales como dinámica de poblaciones y luchas biológicas, predicciones en la bolsa de comercio, computación cuántica, caos y muchos otros temas son estudiados por dichos grupos interdisciplinarios.

Además, las investigaciones de carácter regional relacionadas con radiación ultravioleta, difusión y salinidad de las aguas, sismología, recursos energéticos, ciencias del mar y otros, requieren del aporte de una serie de especialistas que convergen en una problemática común.

La ciencia de hoy requiere de la investigación interdisciplinaria. Se hace necesario reconocer su valor y aplicación no solo a problemas universales, sino también a aquellos de carácter regional. De esta forma, el valor de la investigación aplicada cobra un sentido primordial, pues tiende a resolver problemas de nuestro entorno. La alianza entre la ingeniería y las ciencias básicas es la sustentación de la investigación interdisciplinaria aplicada a la problemática regional. En este sentido, y dada la diversidad profesional de los autores, la revista Facultad de Ingeniería constituye un aporte de excelencia al conocimiento y a las exigencias de la investigación de vanguardia.

Dr. Juan César Flores A. Director de Investigación Universidad de Tarapacá 


\section{EDITORIAL}

\section{THE ROLE INTERDISCIPLINARY STUDIES IN AVANT GARDE RESEARCH}

Presently Science is going through a process of vast development. Interaction among professionals of diverse fields of expertise, in interdisciplinary research teams, is increasing daily with amazing results. One example of this trend is the study of genetic structure sequence and its physical and chemical properties in teams formed by mathematicians, biologists, physicists, chemists and specialists in information technology. Another field where interdisciplinary interaction is observed is mesoscopic physics, where electronic properties in systems of few micrometers at low temperatures, require the participation of engineers, physicists and mathematicians. Likewise, topics such as population dynamics and biological struggles, stock exchange projections, quantum computing, chaos and many other subjects are studied by interdisciplinary research teams.

As in the cases cited, regional research studies, dealing with ultraviolet radiation, water salinity and diffusion, seismology, energetic resources and ocean science, require the participation of scholars representing multiple fields of knowledge.

Today's research in science requires interdisciplinary work. It is therefore necessary to acknowledge its value when solving universal as well as regional problems. The alliance between engineering and science constitutes the foundation of regional interdisciplinary research. Within this context, magazine Facultad de Ingeniería becomes a significant contribution to avant garde knowledge and research.

Dr. Juan César Flores A. Director de Investigación Universidad de Tarapacá 